Historic, Archive Document

Do not assume content reflects current scientific knowledge, policies, or practices. 


$$
\text { - }
$$




\section{PRICE LIST Evergreens, Fruit Trees AND PLANTS}

\section{$\underset{2}{2}=$ \\ IIIIIIIIIIIIIIIIIIIIIIIIIIIIIIIIIIIIIIIIIIIIIIIIIIIIIIIIIIIIIIIIIIIIIIIIIIIIIIIIIIII}

FOR SALE BY

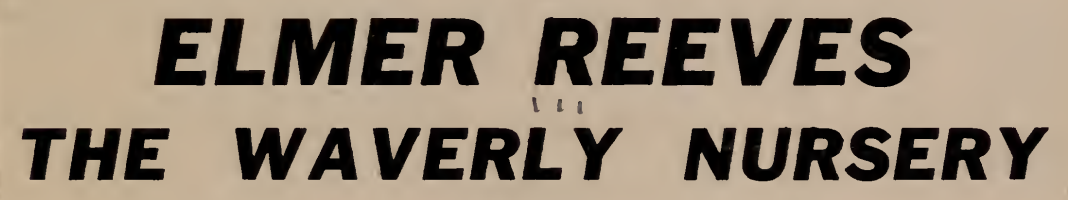

(AT THE SAME LOCATION SINCE 1883)

NORTH-WEST OF I. C. DEPOT

TELEPHONE NO. 375-J

\section{WA VERLY. IOWA}

\section{IIIIIIIIIIIIIIIIIIIIIIIIIIIIIIIIIIIIIIIIIIIIIIIIIIIIIIIIIIIIIIIIIIIIIIIIIIIIIIIIIIIIIII

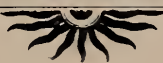

In making these prices I expect to meet any reasonable competition and will gladly correct all mistakes made and replace trees that are unsound or not in good condition when delivered. I want your trade, and can and will do better by you than traveling salesmen can possibly do. Trees will be packed and delivered at depot or express office at rates given in this list, but on large trees the cost of box will be charged. Terms are cash before shipment unless otherwise arrangeed. Certificate of Nursery Inspection furnished with each order shipped. Write for prices on large orders. 


\section{APPLES.}

My apple trees are grown by grafting long scions on apple roots grown on my own grounds. This is the method that experience has shown to produce the best trecs. The varieties are the hardiest and most valuable for this climate, and all trees are absolutely true to name.

All trees should be planted fimly in well prepared ground. Do not cxpcct a tree to do well where a hill cf ccrn will not grow and mature well. I make the uniform price on apple trees of $\$ 40$ per hundred, which is below the prcsent wholesale price, and allow the eustomer to make his own silection of varieties and sizes of trees. I have all sizes of most sorts up to six feet above ground when planted.

\section{SUMMER VARIETIES.}

Duchess, Yellow Transparent, Tetofsky, Red Transparent.

\section{FALL VARIETIES.}

Wealthy, Longfield, Patten's Greening, Eastman, Wolf River, Sugar Loaf.

\section{WINTER VARIETIES.}

Northwestern Greening, Windsor Chief, Gano, Tolman Sweet, Iowa Beauty, Hibernal, Spear, Fameuse or Snow, Meìnda, Salome, Grimes' Golden, Delicious, "Jonathan, King David and many others in small supply. Sweet.

Of crabs I have. Whitney, Hyslop, Minnesota, Mercer and Briars

\section{PLUMS.}

DeSota, Wyant, Forest Garden, Miner. All plums 50 cents each.

\section{CHERRIES}

Early Richmond, :Montmorency and English Morello are best. Four to five feet, 50 cents.

Compass-A cross between plum and cherry, ripe in August. Three to four feet, 40 cents.

\section{PEARS}

Flemish Beauty and Keiffer. These have proven best and all should try a few trees of this choice fruit. Each, 50 cents.

\section{CURRANTS}

Victoria, Red Dutch and White Grape. Two year roots, each $25 \mathrm{c}$. Lee's Prolific, black, each 25 cents.

\section{GOOSEBERRIES.}

Downing and Red Jacket. Each 25 cents.

\section{GRAPES.}

Moore's Early, Worden, Concord, Niagara, each 25 cents.

\section{RASPBERRIES.}

Dozen Per 100

Older, Gregg and Ohio-The best black varieties...

Turner, Cuthbert and Iowa - The reliable red sort. . $\$ 1.00 \quad \$ 5.00$

\section{BLACKBERRIES.}

Snyder and Ancient Britton .................... 1.00 


\section{STRA WBERRIES.}

Progressive, per 100

Senator Dunlap and Aroma ........100 for $\$ 1.00 ; 1,000$ for $\$ 5.00$

August Luther, a very large, choice berry, per 100

$\$ 1.50$

\section{ASPARAGUS}

Conover's Collosal, two year roots......100 for $\$ 1.00 ; 1,000$ for $\$ 5.00$

\section{MISCELLANEOUS.}

White Birch, cut leaved, 4 to 5 feet $\ldots \ldots \ldots \ldots \ldots \$ 1.50$

White Birch, common, 6 to 10 feet $\ldots \ldots \ldots \ldots \ldots \ldots . . .00$

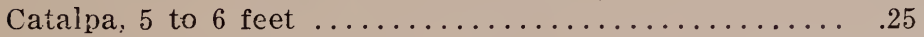

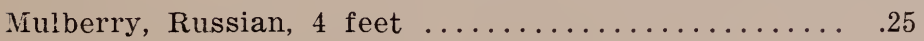

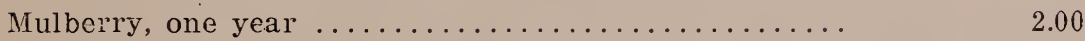

Juneberry, good fruit, resembling huckleberry ..... .25

Snowball, well rooted plants .............25 to .50

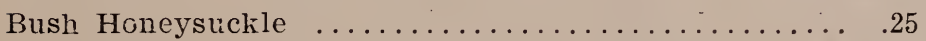

Climbing Honcysuckle, blooms all sunmer........ 25

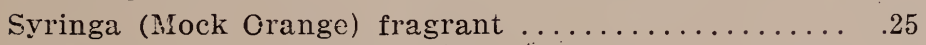

Spirea VanHoutei (Bridal Wreath) white.......25 to .50

Spirea Anthony Waterer, pink and ever bloomer... .25

Spirea Calosa, long fєathery spikes............ .25

Lilac, common white, purple and Persian...........25

Lilac, double white, large dark purple and others of the improved sorts ................. 40

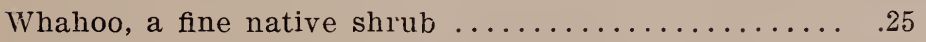

White Flowering Almond, blooms early ......... .25

Pink Flowering Almond, very large and showy..... .25

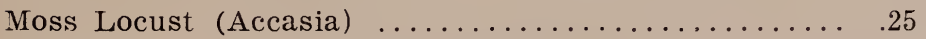

Caragana (pea tree) yellow flowers $\ldots \ldots \ldots \ldots \ldots \ldots .25$

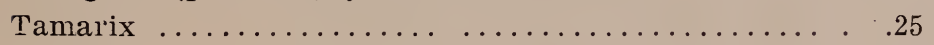

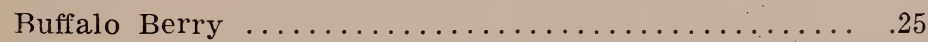

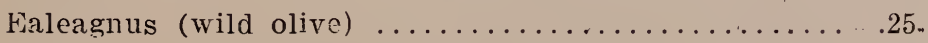

Iris, blue or yellow, gcod clumps $\ldots \ldots \ldots \ldots \ldots \ldots \ldots .25$.

Lillies, Tiger and 'Turk's Cap ............. 10

Lily of the Valley, good clumps .............. .25

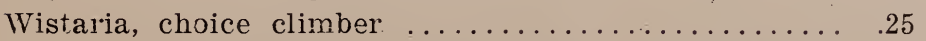

Yucca, resembles century plant, blooms on tall spike. . .25

Hydrangea, vigorcus and hardy, very large blooms... .50

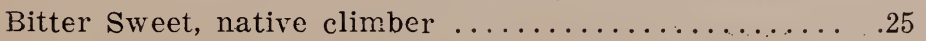

Virginia Creeper (American Ivy) five-leaved Ivy, the best climber.

\section{PEONY}

Per 100

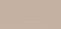


ties, but to encourage planting in satisfactory quantities, I offer a mixture of the best sorts at less than wholsesale price-

Mixed, per hundred $\ldots \ldots \ldots \ldots \ldots \ldots \ldots \ldots \ldots \ldots$

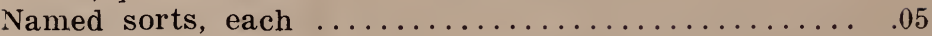

\section{CLEMA'I'IS}

Paniculata, small flowers, white and sweet scented.. .50

Henryii, large white ................... .50

Madam Eoudard Andre, large and bright carmine.... $\quad .50$

Jackmini, large blue and purple .............. .50

\section{ROSES}

Crimson Rambler, fine climber, two year roots...... .50

Dorothy Perkins, pink and white, vigorous........ .50

Baron de Bonsteten, finest dark red............ .50

Frau Karl Druschki, the best white rose........... .50

Paul Neyron, a choice pink with large blooms...... $\quad .50$

Harrison's Yellow, very hardy .............. .50

Rugosa, Russian and very hardy double red rose.... $\quad .50$

\section{SHADE TREES}

American and English Elm, 4 to 6 feet ........ .50

American and English Elm, 10 to 12 feet.......... 1.00

Hard Maple, 8 to 12 feet .............\$1.00 to 2.00

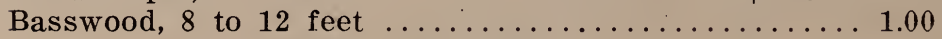

Carolina Poplar Cuttings, per $100 \ldots \ldots \ldots \ldots \ldots \ldots$

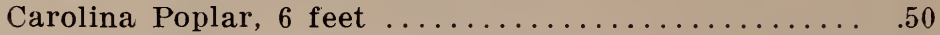

\section{RHUBARB}

Myatt's Linneaus and Strawberry $\ldots \ldots \ldots \ldots \ldots \ldots . .15$

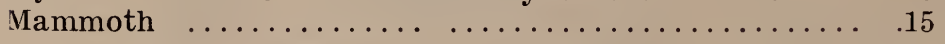

\section{EVERGREENS}

Norway Spruce, 1 foot, per $100 \ldots \ldots \ldots \ldots \ldots \ldots$

Norway Spruce, 2 feet, per $100 \ldots \ldots \ldots \ldots \ldots \ldots$

Norway Spruce, 4 to 6 feet, per $100 \ldots \ldots \ldots \ldots \ldots$

Norway Spruce, choice specimens, 4 to 8 feet, each. 1.00

Scotch Pine, Balsam Fir, White Spruce, and Arbor

Vitae at about same prices as Norway Spruce.

Colorado Blue Spruce, select blue, 2 feet...........

Colorado Blue Spruce, select blue, 3 to 4 feet........

Concolor Fir, a western tree of great beauty and

Douglas Spruce, the tree from which the western

Fire lumber is made. at same prices as Colorado

Blue.

Plant your windbreak this spring. Evcrgreens make the best windbreak and take the least room. Bring plenty of straw to pack your load of trees and so be sure they will grow.

\section{HEDGE PLANTS}

Amoor Privet, 2 year, 2 feet, per $100 \ldots \ldots \ldots \ldots \ldots . .60$

Arbor Vitae, Norway Spruce and various other plants are also used for hedges. 